\title{
Reorganization and development of the trolleybus subsystem in Belgrade
}

\author{
Miroslava Kaluđerovića, Slađana Stankovića, Mara Dabovića , Suzana Mazića \\ a JKP GSP "Beograd", Belgrade
}

\begin{tabular}{|c|c|}
\hline ARTICLE INFO & ABSTRACT \\
\hline $\begin{array}{l}\text { DOI: } 10.31075 / \text { PIS.65.04.07 } \\
\text { Professional paper }\end{array}$ & \multirow{6}{*}{$\begin{array}{l}\text { The IME (Identity - Mobility - Ecology) Project, initiated by the City of Belgrade, } \\
\text { aims to bring together a number of different projects focused on strengthening } \\
\text { the city identity, promoting and implementing the concept of sustainable mobility } \\
\text { and enhancing environmental awareness. The implementation of this project } \\
\text { significantly influences the appearance, concept and organization of the } \\
\text { trolleybus subsystem in the central city area. The extension of the pedestrian } \\
\text { zone in the city centre must continue to ensure the functioning of public transport } \\
\text { in order to meet the needs of the city's residents to reach the desired destination } \\
\text { in an easy, simple and safe way. The main goal of the analysis Reorganization } \\
\text { and Development of the Trolleybus subsystem in Belgrade, is to find the optimal } \\
\text { solution for reorganization of the existing trolleybus line network as well as further } \\
\text { development directions of the trolleybus subsystem as a significant sustainable } \\
\text { city mobility factor. }\end{array}$} \\
\hline $\begin{array}{l}\text { Received: 10/12/2019 } \\
\text { Accepted: 20/12/2019 }\end{array}$ & \\
\hline $\begin{array}{l}\text { Selected paper from 7th } \\
\text { International conference } \\
\text { "TOWARDS A HUMANE CITY" }\end{array}$ & \\
\hline $\begin{array}{l}\text { Corresponding author: } \\
\text { suzana.mazic@gsp.co.rs }\end{array}$ & \\
\hline Keywords: & \\
\hline $\begin{array}{l}\text { Reorganization } \\
\text { Development } \\
\text { Trolleybus subsystem }\end{array}$ & \\
\hline
\end{tabular}

\section{INTRODUCTION}

Within the IME Project, several sub-projects have been defined, among which is one of the most significant, and also the most demanding, the Extension of the Pedestrian Zone of Knez Mihailova Street. The realization of this project significantly influences the appearance, concept and organization of the public transport of passengers in the central city area.

For many years, the concentration of significant activities in the central city area, as a consequence of the monocentric organization of urban space, had a direct impact on the formation of intensive passenger flows and their directing towards the central city area. Accordingly, the public transport line network was formed with direct penetration into the city center, as the goal destination for most passengers.

\section{INPUT PARAMETERS}

The input parameters for the analysis are defined through the infrastructure projects:

- The project for construction of a new trolleybus-bus terminal "Dunavska" in Dunavska Street;
- The project of construction of trolleybus corridor Cvijićeva - Jaše Prodanovića - Vanizelosova Gundulićev venac - Dunavska Street with a line branch through Dobračina Street to the trolleybus depot "Dorćol";

- Procurement of trolleybuses with IMC (In Motion Charging) system for up to 20 kilometers;

- The project of construction of a new underground garage "Studentski trg";

- Abolition of the existing trolleybus terminus "Studentski trg";

- Project design of the route Čingrijina Street from Bulevar Kralja Aleksandra to Batutova Street with associated infrastructure - planned construction of a new trolleybus-bus terminus "Zvezdara 2" at the corner of Aradska and Milana Rakića Streets;

- SMT Project section Borska - Petlja "Lasta" planned construction of a trolleybus network on the corridor from Paunova Street to the terminus "Medaković 3".

Taking into account all the above projects and plans and considering the current state of the public transport line network, the possible directions for the development and reorganization of trolleybus lines were analyzed. 


\section{TROLLEYBUS TODAY}

The last fleet renewal was carried out in 2011 and included the procurement of modern low-floor vehicles with energy recuperation and other technical solutions implemented in the latest generations of trolleybuses.

Characteristics of the trolleybus subsystem:

- trolleybus contact network length of $28,3 \mathrm{~km}$

- contact network voltage of $600 \mathrm{~V}$

- number of rectification stations - 21 (2 exclusively for trolleybuses, 10 mixed for tram - trolleybus and 9 for trams built in the period 1950-1960)

- depot " Dorćol " was built in 2000 (rebuilt after the fire)

- number of lines 7

- the line network length of $55,8 \mathrm{~km}$

- mean line length of $8,0 \mathrm{~km}$

- 123 trolleybuses in inventory, of which 97 solo and 21 articulated and 5 e-buses

- average fleet age of 11,31 years

- 94 trolleybuses in operation at peak hours

- maximum frequency on the section (Vasina Street) of about 60 vehicles/hour

- average daily (working day) number of 158.832 passengers transported by the trolleybus subsystem

- participation of the trolleybus subsystem in the total number of transported passengers of about $9 \%$

The following figure shows the existing trolleybus subsystem line network.

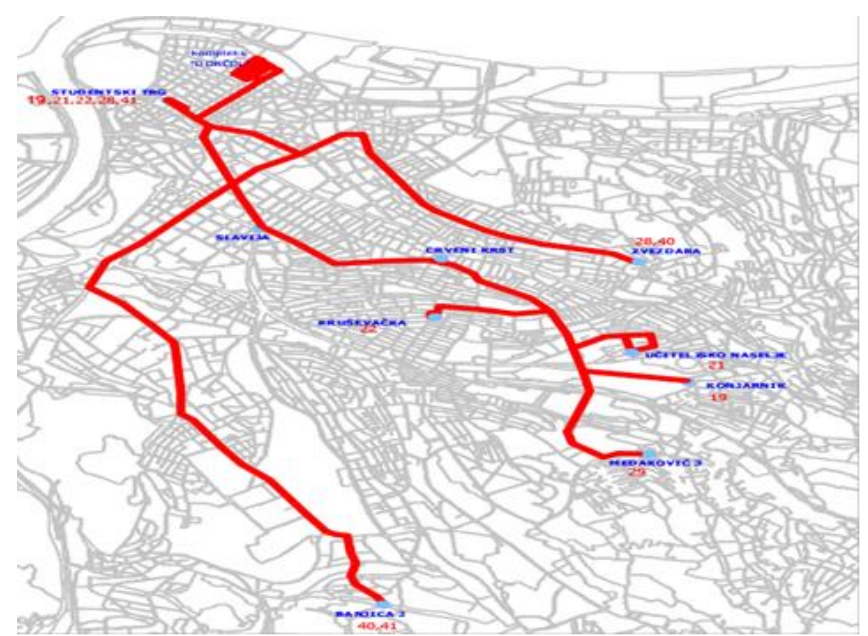

Figure 1. The existing trolleybus subsystem line network

Elements of operation of the existing trolleybus line network based on the winter timetable (22.01.2019) are given in the following table:

\begin{tabular}{|c|c|c|c|c|c|c|c|c|c|c|}
\hline Line & Name of the line & \multicolumn{2}{|c|}{ vehicle-type } & $N($ vor $)$ & $L(\mathrm{~km})$ & To $(\min )$ & $\begin{array}{c}v_{0} \\
(\mathrm{~km} / \mathrm{h})\end{array}$ & $i(\min )$ & $f(100 / h)$ & a \\
\hline 19 & Studentski trg - Konjamik & 5 & & 5 & 7,0 & 80 & 10,6 & 16 & 3,8 & 379 \\
\hline 21 & Studentski trg - Uätel jsko naselje & 9 & & 9 & 6,7 & 74 & 10,8 & 8 & 7,3 & 737 \\
\hline 22 & Studentski itrg - Kruševačcka & 8 & & 8 & 6,3 & 77 & 9,8 & 10 & 6,2 & 630 \\
\hline 29 & Studentski trg - Medakovic 3 & 18 & 6 & 24 & 8,0 & 90 & 10,7 & 4 & 16,0 & 1.852 \\
\hline 28 & Studentski trg - Zvezdara & 7 & & 7 & 5,4 & 65 & 10,0 & 9 & 6,5 & 653 \\
\hline 40 & Zvezdara - Banjica 2 & 18 & 2 & 20 & 12,5 & 110 & 13,6 & 6 & 10,9 & 1.166 \\
\hline 41 & Studentski itrg-Banjica 2 & 14 & 7 & 21 & 9,9 & 103 & 11,5 & 5 & 12,2 & 1.476 \\
\hline & TOTAL & 79 & 15 & 94 & 559 & & & & & 6.892 \\
\hline
\end{tabular}

\section{DEVELOPMENT OF THE TROLLEYBUS SYSTEM IN BELGRADE}

\subsection{Development of the trolleybus network}

Development of the trolleybus system in Belgrade is defined by the city development planning documents as well as the GSP "Beograd" development projects.

According to the GUP, by 2021, the development of trolleybus transport has not been specifically treated, as it corresponds to the bus system in capacity. The possibility of the network extention is left open, where it's technologically and economically justified for the replacement of buses, taking into account the integrity of the trolleybus network.

In accordance with the above input parameters, and considering the reconstruction of Trg republike and the extension of the pedestrian zone in the central city area, it is necessary to reorganize the trolleybus line network. The procurement of new IMC trolleybuses opens the possibility of the network upgrading and adapting to new conditions. IMC trolleybuses, with their own properties and technical characteristics will contribute to the development of the entire project for the organization of the central city area in accordance with modern trends and high standards.

Reduction of polutant emissions, more efficient energy consumption, noise reduction, non-use of the network in the central city area are the benefits of acquiring new IMC trolleybuses and reorganizing the trolleybus subsystem line network.

In accordance with the set requirements, one of the possible new line network variants is shown in the following figure:

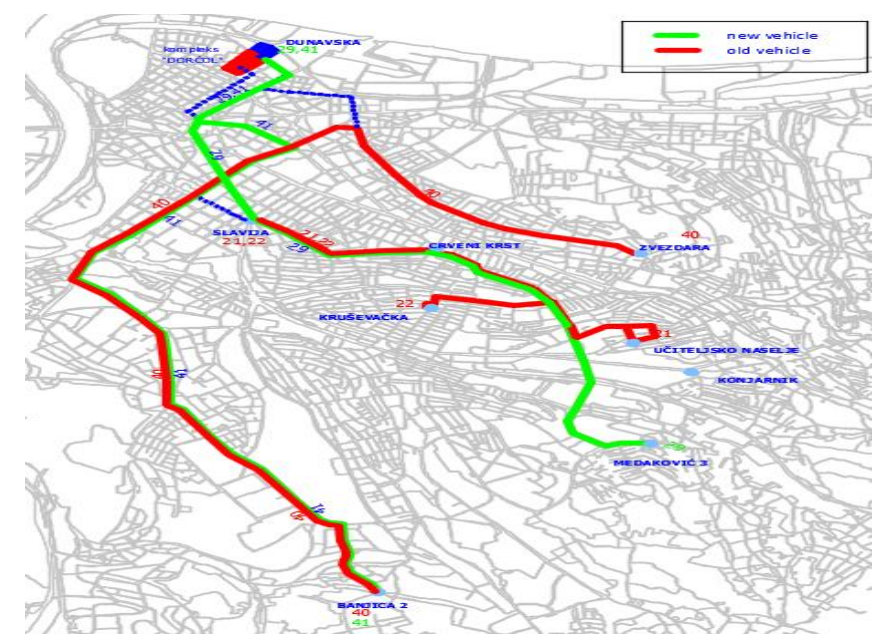

Figure 2. Proposal for a new trolleybus line network 
The proposal for a new network implies the operation of new IMC vehicles on lines passing through the city center. The existing vehicles operate on the lines which terminate on the perimeter of the central city area or pass along the perimeter of the central city area. One of the conditions, which also has to be met by the new line network, is to maintain the existing capacity on trolleybus routes as well as the rotation speed.

In addition to modern trolleybuses, the operation of ebuses is also planned for the central city area, which would reduce the emission of harmful gases and the noise level.

In line with the concept of sustainable development and development of environmental awareness, a new line (service) "Vrabac (Sparrow)" has been introduced, which is a real attraction for both tourists and residents of Belgrade. The service is free, it operates within the pedestrian zone, with 6-passenger electric vehicles.

\subsection{Construction of a new trolleybus-bus terminal in Dunavska Street at Dorćol}

In order to realize the described concept of trolleybus network, the construction of a new terminal is planned, which represents the realization of the plan defined urban development program for Belgrade based on dislocation of the central city termini "Studentski trg" and "Trg Republike" to the perimeter of the central zone.

The trolleybus - bus terminal will be built on the site of approximately $20.400 \mathrm{~m} 2$ in Dunavska Street, with necessary supporting facilities.

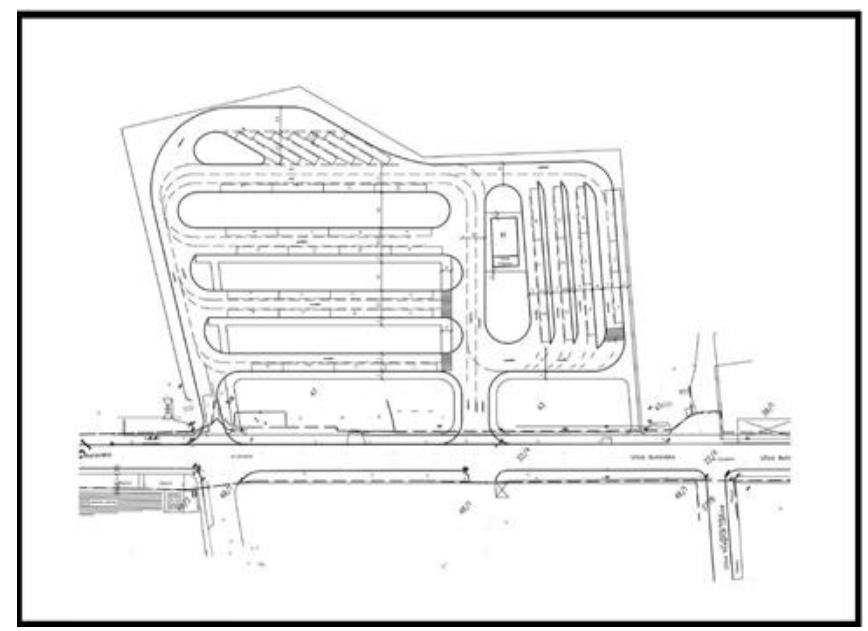

Figure 3. Conceptual design of the new trolleybus - bus terminal

\subsection{The new trolleybus depot "Kosmaj 2"}

According to Detailed Regulation Plan, "Kosmaj 2" settlement in Voždovac municipality presents a purpose-defined area for the construction of a new trolleybus depot for accommodation and maintenance of 150 trolleybuses.

The construction of a new trolleybus depot is necessary, since the existing depot at Dorcol is spatially insufficient for the existing number of trolleybuses, therefore further development of the trolleybus network and the procurement of new vehicles requires timely provision and construction of a new depot.

\section{5 . CONCLUSION}

Formation of the entire proposed line network, construction of a bus-trolleybus terminal at Dorćol and a new trolleybus depot will result in an extended and more efficient trolleybus line network. Further expansion of the trolleybus network will allow the replacement of a number of bus lines by trolleybus lines, which will lead to:

- reduction of polutant emissions;

- more efficient energy consumption;

- noise reduction;

- reduction of the system costs per pkm.

The quality level of transport service will increase, and therefore the attractiveness of public transport.

\section{References}

[1] City of Belgrade (2021). The Master Plan of Belgrade

[2] PTV, DDC, GISTEC, PNZ, TREDIT (2008). The Smartplan of Belgrade

[3] GSP Beograd (1996). Study on the Development of Trolleybus Traffic in Belgrade until 2010

[4] GSP "Beograd (2019). Executive Plan for the Number of Vehicles by Operators, Depots and Lines from 22.01.2019. 